\title{
Product Development Based Sensory Evaluation and Physicochemical Characterization of Cashew Apple Bagasse Jam and Technology Transfer to Community
}

\author{
Piyaluk Nurerk ${ }^{1}$ and Sirisopa Junden ${ }^{2,3, *}$ \\ ${ }^{I}$ Functional Materials and Nanotechnology Center of Excellence, School of Science, Walailak University, \\ Nakhon Si Thammarat 80160, Thailand \\ ${ }^{2}$ Program in Professional Culinary Arts, School of Management, Walailak University, \\ Nakhon Si Thammarat 80160, Thailand \\ ${ }^{3}$ Food Technology and Innovation Research Center of Excellence, Walailak University, \\ Nakhon Si Thammarat 80160, Thailand
}

("Corresponding author's e-mail: sirisopa.ju@wu.ac.th)

Received: 23 April 2021, Revised: 19 June 2021, Accepted: 23 June 2021

\begin{abstract}
Jam type product was successfully developed using cashew apple bagasse from cashew apple juice manufacturing. Proximate analysis of cashew apple bagasse was carried out including soluble and insoluble fiber content. Cashew apple juice was added to 3 different ratios to produce jam type products and their sensory quality was evaluated; 5 percentage cashew apple juice content in Jam product was favored in all sensory parameters. Physicochemical properties of the jam product were analyzed including proximate composition, dietary fiber content, color, viscosity, $\mathrm{pH}$ and water activity. The optimum condition to produce cashew apple bagasse prototype was transferred to staffs of local company of Cashewy Phuket Cooperation Limited, Thailand through hands-on training for description and demonstration jam production. The assessment of before and after training was statistically significant at the 0.05 level of significance. The overall evaluation score of technology transfer has obtained the level of most satisfied with the mean score of 4.59 .
\end{abstract}

Keywords: Cashew apple bagasse, Jam, Dietary fiber, Technology transfer, Community

\section{Introduction}

Cashew nut tree is in a Anacardiaceae family, Anacardium occidentale species, which plentifully found in the tropical regions due to the humidity and warm [1]. The cashew can be abundantly found in the southern part of Thailand. Since a cashew apple is tender and juicy with a sour taste, it is normally used as a food ingredient. However, the ripe cashew apple contains abundant of tannin causing rapid spoilage, the cashew can be fermented to produce cashew juice, wine, and vinegar [2]. Furthermore, the cashew has been manufactured juice in many industries of Thailand. It has been reported that phenolic compounds, vitamin $\mathrm{C}$, and antioxidants are highly contained in cashew juice [3]. However, the cashew juice production process residues cashew apple containing both insoluble and soluble dietary fiber. The insoluble fiber can help in the human digestive system meanwhile the soluble fiber plays important role in keeping foods in the stomach for a longer time. Soluble dietary fiber also helps to move food slowly into the small intestine resulting in slow absorption of nutrients which is good for a person with diabetes and high cholesterol in blood [4-6]. Reported nutrients of cashew apple bagasse include $0.30-9.0 \%$ of protein, $0.16-0.66 \%$ of fat, $10.95-14.52 \%$ of carbohydrate and 0.27 - almost $10 \%$ [7-10]. The cashew apple bagasse is widely produced several products such as jams, jellies, and beverages [7].

Jam is a food product that has intermediate moisture. It is able to be produced by boiling fruits, adding sugar, pectin and acids, respectively; food additives may also be added including preservatives, food coloring, and flavoring additive. Additionally, the jam should have a harmonious texture and sufficient viscosity and firmness to be applied to various foods and desserts $[11,12]$. There are 2 types of jam, the first type contains more than $45 \%$ by weight of fruit and the second type presents more than 33 $\%$ by weight of fruit. Jam can be produced by a single fruit or mixed fruit. Jam is also a spread food production which is in the first place of a market share in Thailand which provide market expansion 
growth of $3.9 \%$ in 2018. However, jam still contains high sugar levels, which is against the current health trend of people, contributing to the limitation of the average growth in the market share [13].

Therefore, in this work, the cashew apple bagasse jam product was produced from the cashew apple bagasse and its juice. Various concentration of juice added cashew apple bagasse jam was first investigated based on sensory evaluation. The most favorable jam was investigated physicochemical properties including color, viscosity, proximate analysis. The jam production technology was secondly transferred to staffs of local company through the hands-on training.

\section{Materials and methods}

\section{Raw materials}

Cashew apple bagasse and concentrated cashew juice were obtained from Cashewy (Phuket, Thailand). Sugar was from Mitr Phol (Mitr Phol Sugar Corporation., Ltd., Thailand). The drinking water was purchased from Nestle (Nestle (Thai) Corporation., Ltd., Thailand). Citric acid with food grade was obtained from Best Order (Best Order Co., Ltd.). Pectin was from Special Food (Special Food Corporation., Ltd., Thailand) and salt was purchased from Prung Thip (Thai Refines Salt Co., Ltd., Thailand).

\section{Cashew apple bagasse preparation}

A $500 \mathrm{~g}$ of cashew residues were thoroughly washed with $1.0 \mathrm{~L}$ of drinking water, then squeezed and finely chopped into small pieces. The washed cashew apple bagasse was subsequently streamed at $105 \pm 2{ }^{\circ} \mathrm{C}$ for 20 minutes and cooled down to ambient temperature $\left(30 \pm 2{ }^{\circ} \mathrm{C}\right)$.

\section{Nutritional values analysis of cashew apple bagasse}

The washed cashew apple bagasse was evaluated nutritional values in terms of protein, carbohydrate, fat, moisture, ash, crude dietary fiber, soluble dietary fiber, insoluble dietary fiber, and energy according to AOAC methodology [14].

\section{Cashew apple bagasse jam production}

Cashew jam consisted of cashew apple bagasse, cashew juice, water, pectin, sugar and salt. Varying concentrations of cashew juice included 0, 5, 10 and $15 \% \mathrm{w} / \mathrm{w}$ were investigated. All ingredients were mixed and heated until the temperature reached $90 \pm 2{ }^{\circ} \mathrm{C}$ for $5 \mathrm{~min}$ under stirring. During heating, $\mathrm{pH}$ was simultaneously adjusted to $2.8-3.2$ by citric acid. Meanwhile, sugar was slowly added and continuously stirred until the total soluble solid was between 65 - $68{ }^{\circ}$ Brix. Subsequently, the mixture was continuously heated until the temperature reached $105 \pm 2{ }^{\circ} \mathrm{C}$ for $5 \mathrm{~min}$. The jam was cooled down to $90{ }^{\circ} \mathrm{C}$ and then loaded in sealed containers.

\section{Physicochemical analysis of cashew apple bagasse jam}

The color value (CIE L* $\mathrm{a}^{*} \mathrm{~b}^{*}$ ) was investigated using Cm-350d Colorimeter (Minota, Japan). The texture was measured in term of rupture strength using Texture Analyser Model TA-XTplus (Surrey, England). The analysis was performed 10 replications. Water activity $\left(\mathrm{a}_{\mathrm{w}}\right)$ was measured using the EZ200 water activity meter (Freund, Japan). The chemical composition of protein, carbohydrate, fat, moisture, ash, and crude dietary fiber as well as $\mathrm{pH}$ and total soluble solid were determined by the method of AOAC [14].

\section{Sensory evaluation}

The sensory analysis of developed treatments of cashew apple bagasse jam were evaluated by 9point hedonic liking scale by 30 untrained taste panels [15]. The $30 \mathrm{~g}$ of cashew apple bagasse jam was placed in a plastic cup and served with bread slices $\left(2.5 \times 2.5 \mathrm{~cm}^{2}\right)$. The 9-Point Hedonic Scale method was used to evaluate the test. The liking scale points were ranged from 1-dislike extremely to 9-like extremely with the sensory characteristics of color, smell, taste, sweetness, sourness, flavor, texture and overall liking. The developed cashew apple bagasse jam production obtained the highest score was selected for further study.

\section{Statistical analysis}

The data was expressed as mean \pm standard deviation. Statistical variance was analyzed by 1-way ANOVA. Duncan multiple range tests was used to determine the significant differences among the various samples in triplicate. Data were analyzed by Statistical Package for Social Science (SPSS) version 
19 (SPSS Inc., Chicago, II, USA at $p$-value $<0.05$ of significance. The data of quizzes before and after training were expressed as mean \pm standard deviation. Data were analyzed by an analysis of variance and t-test. The 3 parts of the questionnaire were performed on training evaluation. The first part was general information, the second part was satisfaction with the training processes and the last part was the suggestion for development. The scores were analyzed by frequency and percent, and mean, respectively, the last part was presented in a format of oral presentation.

\section{Technology transfer of cashew apple bagasse jam}

The jam production technology was transferred to 30 participants including executives and staff of the production department of The Cashewy Phuket (Thailand) Co., Ltd., Thalang district, Phuket Province, Thailand. The hands-on training was performed via description and demonstration of the nutritional values and the most favorable cashew apple bagasse jam production prototype. The participants were taken the pre-test and post-test of the training. The training processes were evaluated using the satisfaction assessment form which included procedures and service processes (registration, contact, cooperation and information, service, and systematic work), lecturers and service staffs (goodnatured, sociable, and welcoming), facilities (venue, food, audio visual equipment, training materials), knowledge adaptation in career or dairy life, suitability of contents, suitability of lecturers (knowledge, ability, lecturing technic), training duration (number of days), training period (day/month/training season), worthiness compared to wasted time and cost and overall evaluation. The interpretation of satisfaction level was ranged from 1 of least to 5 of most.

\section{Results and discussion}

Nutritional values analysis of cashew apple bagasse

The nutritional value of cashew apple bagasse demonstrated in Table 1. The high amount of protein content was found to be $2.75 \pm 0.08 \%$. This might be due to the abundant in sulfur atoms which are the component of amino acid $[9,16]$. The total fat was $0.31 \pm 0.12 \%$ which was lower, whereas the high amount of total carbohydrate was comparable found to be $13.94 \pm 0.03$. [8-10]. The high moisture content was $71.04 \pm 0.65 \%$, the ash contained $0.17 \pm 0.05 \%$ and the high content of crude fiber content was $11.79 \pm 0.16 \%$ which were comparable to variety of cashew apples in India and Brazil [7,8].

The energy of $100 \mathrm{~g}$ of cashew apple bagasse was determined as $78.83 \pm 0.32 \mathrm{kcal}$. The cashew apple bagasse highly composed of insoluble dietary fiber. This could reduce the adsorption time of remained food in the large intestine, leading to faster pushing stool process into the distal colon [17]. Chewed foods in the digestive tract are called chyme and after ingestion of foods containing soluble dietary fiber into the stomach, chyme becomes more viscous. This viscous chyme is able to keep foods in the stomach for a longer time and also helps to move food slowly into the small intestine, causing slow absorption of nutrients which is good for a person with diabetes and high cholesterol in the blood $[18,19]$.

Table 1 Nutritional values of cashew apple bagasse (100 g).

\begin{tabular}{cc}
\hline Nutritional values & Amount (\% w/w) \\
\hline Protein (\%) & $2.75 \pm 0.08$ \\
Total carbohydrate (\%) & $13.94 \pm 0.03$ \\
Fat (\%) & $0.31 \pm 0.12$ \\
Moisture (\%wet basis) & $71.04 \pm 0.65$ \\
Ash (\%) & $0.17 \pm 0.05$ \\
Crude fiber (\%) & $11.79 \pm 0.16$ \\
Soluble dietary fiber (\%) & $8.08 \pm 0.21$ \\
Insoluble dietary fiber (\%) & $91.92 \pm 1.22$ \\
Energy (kcal) & $78.83 \pm 0.32$ \\
\hline
\end{tabular}

\section{The addition of cashew juice}

The amount of cashew juice was mixed into the cashew jam by varying concentrations included 0 , 5, 10 and $15 \% \mathrm{w} / \mathrm{w}$. Different colors of cashew apple bagasse jam were noticeable by naked eyes and found to be brown to deep brown with the increase in cashew juice (Figure 1). The darker color might be due to the oxidative degradation of anthocyanins to phenolic acids under heat treatment [20]. 


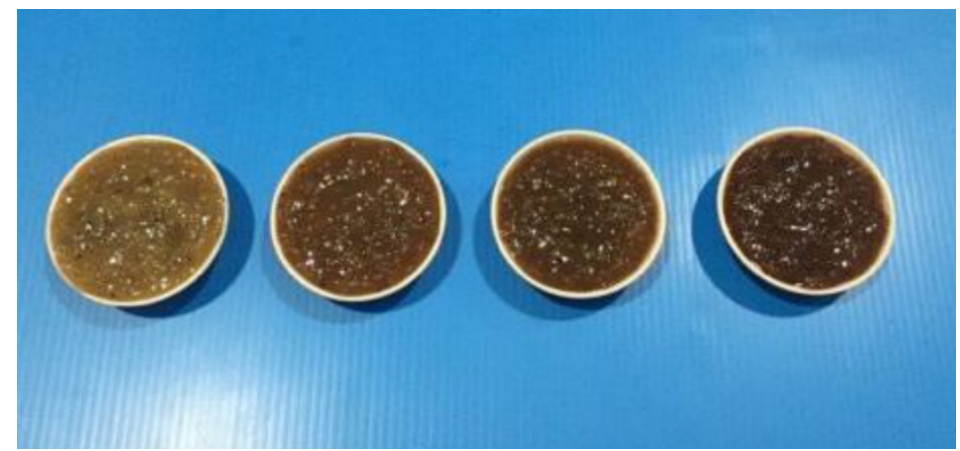

Figure 1 Different colors of cashew juice added 0, 5, 10 and $15 \% \mathrm{w} / \mathrm{w}$ of cashew apple bagasse jam (from left to right).

As shown in Table 2, the sensory evaluation of cashew apple bagasse jam demonstrated that the $5 \%$ of cashew juice significantly provided the most favorable for all characteristics. Therefore, the treatment of $5 \%$ cashew juice added cashew apple bagasse jam was selected for further study.

Table 2 Sensory evaluation various of cashew juice added cashew apple bagasse jam.

\begin{tabular}{lcccc}
\hline \multirow{2}{*}{$\begin{array}{c}\text { Sensory } \\
\text { characteristics }\end{array}$} & \multicolumn{3}{c}{ Different concentration of cashew juice added into cashew apple bagasse jam } \\
\cline { 2 - 5 } & $\mathbf{0 \%}$ & $\mathbf{5 \%}$ & $\mathbf{1 0} \%$ & $\mathbf{1 5 \%}$ \\
\hline Color & $6.10 \pm 1.30^{\mathrm{b}}$ & $7.23 \pm 1.41^{\mathrm{a}}$ & $7.07 \pm 1.05^{\mathrm{a}}$ & $6.07 \pm 1.17^{\mathrm{b}}$ \\
smell & $6.47 \pm 1.31^{\mathrm{b}}$ & $7.07 \pm 0.91^{\mathrm{a}}$ & $6.67 \pm 0.99^{\mathrm{ab}}$ & $6.27 \pm 1.11^{\mathrm{b}}$ \\
Taste & $6.60 \pm 1.19^{\mathrm{b}}$ & $7.40 \pm 1.43^{\mathrm{a}}$ & $7.10 \pm 1.16^{\mathrm{ab}}$ & $6.60 \pm 1.00^{\mathrm{b}}$ \\
Sweetness & $6.70 \pm 1.18^{\mathrm{a}}$ & $6.97 \pm 1.25^{\mathrm{a}}$ & $7.10 \pm 1.40^{\mathrm{a}}$ & $6.70 \pm 1.02^{\mathrm{a}}$ \\
Sourness & $6.17 \pm 1.05^{\mathrm{b}}$ & $6.80 \pm 1.06^{\mathrm{a}}$ & $6.80 \pm 1.21^{\mathrm{a}}$ & $6.50 \pm 1.14^{\mathrm{ab}}$ \\
Flavor & $6.80 \pm 1.00^{\mathrm{a}}$ & $7.17 \pm 1.34^{\mathrm{a}}$ & $6.97 \pm 1.07^{\mathrm{a}}$ & $6.73 \pm 1.39^{\mathrm{a}}$ \\
Texture & $6.43 \pm 1.45^{\mathrm{a}}$ & $6.83 \pm 1.64^{\mathrm{a}}$ & $6.83 \pm 0.91^{\mathrm{a}}$ & $7.13 \pm 1.28^{\mathrm{a}}$ \\
Overall liking & $6.47 \pm 0.90^{\mathrm{b}}$ & $7.60 \pm 1.35^{\mathrm{a}}$ & $7.37 \pm 0.93^{\mathrm{a}}$ & $7.10 \pm 1.18^{\mathrm{a}}$ \\
\hline
\end{tabular}

*a, b represented a statistically significant difference $(p \leq 0.05)$.

\section{Physical properties of developed cashew residue jam}

The developed cashew apple bagasse jam was investigated the physical properties as presented in Table 3. The result of color measurement showed that the lightness $\left(\mathrm{L}^{*}\right)$, redness $\left(\mathrm{a}^{*}\right)$, and yellowness (b*) were $25.88 \pm 0.19,23.07 \pm 0.20$ and $28.51 \pm 1.42$, respectively. The values of rupture strength and adhesiveness were $264.02 \pm 0.97$ and $235.62 \pm 0.05 \mathrm{~g} \mathrm{~s}^{-1}$, respectively.

Table 3 Physical properties of developed cashew apple bagasse jam.

\begin{tabular}{cc}
\hline Physical properties & Results \\
\hline Color values & \\
$\mathrm{L}^{*}$ & $25.88 \pm 0.19$ \\
$\mathrm{a}^{*}$ & $23.07 \pm 0.20$ \\
$\mathrm{~b}^{*}$ & $28.51 \pm 1.42$ \\
Rupture strength $\left(\mathrm{g} \mathrm{s}^{-1}\right)$ & $264.02 \pm 0.97$ \\
Adhesiveness $\left(\mathrm{g} \mathrm{s}^{-1}\right)$ & $235.62 \pm 0.05$ \\
\hline
\end{tabular}

\section{Chemical properties of developed cashew apple bagasse jam}

The developed cashew apple bagasse jam was investigated the chemical properties. As demonstrated in Table 4, the composition of protein, total carbohydrate, fat, moisture, ash and crude fiber $(\%)$ were $1.18 \pm 0.01,66.64 \pm 0.13,0.10 \pm 0.02,30.38 \pm 0.54,0.68 \pm 0.15$ and $1.02 \pm 0.39$, respectively. 
The energy was determined as $272.18 \pm 0.54 \mathrm{kcal}$ per $100 \mathrm{~g}$ of cashew apple bagasse jam. The percentage composition of soluble and insoluble dietary fiber was $26.46 \pm 0.34$ and $73.54 \pm 1.25$, respectively. The soluble dietary fiber consists of pectin, gum and mucilage which are abundantly found in fruit whereas the insoluble dietary fiber included cellulose, hemicellulose, and lignin are insoluble component of the cell wall which are good water absorptivity [21,22]. Since insoluble dietary fiber efficiently adsorbs water, it facilitates the faster excretion process avoiding colon tumor formation for long-term consumption $[23,24]$. Furthermore, the $\mathrm{pH}$ of the jam was $2.8 \pm 0.01$ with a water activity $\left(\mathrm{a}_{\mathrm{w}}\right)$ of $0.65 \pm$ 0.11 and soluble solid of $65 \pm 0.00^{\circ}$ Brix. These properties were acceptable as the standard permission of the Ministry of Public Health of Thailand that the $\mathrm{pH}$ range of jam should be ranged from 2.8 to 3.5 with the water composition more than $65 \% \mathrm{w} / \mathrm{w}$ [25]. In addition, the jam production under $60-65{ }^{\circ} \mathrm{Brix}$ of soluble solid of and $2.0-3.5$ of $\mathrm{pH}$ facilitates the stability of pectin which is related to the jam formation [11].

Table 4 Chemical analysis of developed cashew apple bagasse jam.

\begin{tabular}{cc}
\hline Chemical characteristics & Results \\
\hline Protein (\%) & $1.18 \pm 0.01$ \\
Total carbohydrate (\%) & $66.64 \pm 0.13$ \\
Fat (\%) & $0.10 \pm 0.02$ \\
Moisture (\% wet basis) & $30.38 \pm 0.54$ \\
Ash (\%) & $0.68 \pm 0.15$ \\
Crude fiber (\%) & $1.02 \pm 0.39$ \\
Soluble dietary fiber (\%) & $26.46 \pm 0.34$ \\
Insoluble dietary fiber (\%) & $73.54 \pm 1.25$ \\
Energy (kcal /100 g) & $272.18 \pm 0.54$ \\
pH & $2.8 \pm 0.01$ \\
Water activity ( $\left.\mathrm{a}_{\mathrm{w}}\right)$ & $0.65 \pm 0.11$ \\
Total soluble solid $\left({ }^{\circ}\right.$ Brix) & $65 \pm 0.00$ \\
\hline
\end{tabular}

\section{Technology transfer of cashew apple bagasse jam}

The score of pre-test and post-test of training 30 participants were collected and analyzed as demonstrated in Table 5. The mean score of pre-test was $11.60 \pm 3.14$ which was a statistically significant difference of the mean score of post-test of $17.97 \pm 1.52$. This result showed that the participants could be obtained the knowledge and understand more about the cashew apple bagasse jam after joined the training [26]. The assessment of the training processes was shown in Table 6. The gender included male 10 participants and female 20 participants. The age range included 20 - 35 year $(26.67 \%)$, 36 - 50 year $(63.33 \%)$ and 61 - 60 year $(10.00 \%)$. Most education levels were high school $(90.00 \%)$. Only facilities (venue, food, audio visual equipment, training materials) were obtained the level of very satisfaction with the mean score of $4.43 \pm 0.77$. Most assessment characteristics included, training process (registration, contact, cooperation and information, service and systematic work), lecturers and service staffs (good-natured, sociable, and welcoming), knowledge adaptation in career or dairy life, suitability of contents, suitability of lecturers (knowledge, ability, lecturing technic), training duration (number of days), training period (day/month/training season), worthiness compared to wasted time and cost and overall evaluation score of technology transfer has belonged to the level of most satisfied with the mean scores ranged from $4.57 \pm 0.50$ to $4.63 \pm 0.49$.

Table 5 Scores of pre-test and post-test of training.

\begin{tabular}{cccccc}
\hline Test & N & Mean & SD & t & Sig. \\
\hline Pre-test & 30 & 11.60 & 3.14 & 11.537 & 0.000 \\
Post-test & 30 & 17.97 & 1.52 & & \\
\hline
\end{tabular}


Table 6 Satisfaction levels of the participants in the training processes.

\begin{tabular}{|c|c|c|c|c|c|c|c|c|}
\hline \multirow[b]{2}{*}{ Process } & \multicolumn{5}{|c|}{ Satisfaction level } & \multirow[b]{2}{*}{ Mean } & \multirow[b]{2}{*}{ SD } & \multirow{2}{*}{$\begin{array}{c}\text { Interpret } \\
\text { ation }\end{array}$} \\
\hline & $\begin{array}{l}\text { Most } \\
\text { (5) }\end{array}$ & $\begin{array}{l}\text { Very } \\
\text { (4) }\end{array}$ & $\begin{array}{l}\text { Fair } \\
\text { (3) }\end{array}$ & $\begin{array}{l}\text { Less } \\
(2)\end{array}$ & $\begin{array}{l}\text { Least } \\
\text { (1) }\end{array}$ & & & \\
\hline $\begin{array}{l}\text { 1. Procedures and } \\
\text { service processes }\end{array}$ & $\begin{array}{c}17 \\
(56.67 \%)\end{array}$ & $\begin{array}{c}13 \\
(43.33 \%)\end{array}$ & - & - & - & 4.57 & 0.50 & $\begin{array}{c}\text { Most } \\
\text { satisfied }\end{array}$ \\
\hline $\begin{array}{l}\text { 2. Lecturers and } \\
\text { service staff }\end{array}$ & $\begin{array}{c}18 \\
(60.00 \%)\end{array}$ & $\begin{array}{c}12 \\
(40.00 \%)\end{array}$ & - & - & - & 4.60 & 0.50 & $\begin{array}{c}\text { Most } \\
\text { satisfied }\end{array}$ \\
\hline 3. Facilities & $\begin{array}{c}18 \\
(60.00 \%)\end{array}$ & $\begin{array}{c}7 \\
(23.33 \%)\end{array}$ & $\begin{array}{c}5 \\
(16.67 \%)\end{array}$ & - & - & 4.43 & 0.77 & $\begin{array}{c}\text { Very } \\
\text { satisfied }\end{array}$ \\
\hline $\begin{array}{l}\text { 4. Knowledge } \\
\text { adaptation }\end{array}$ & $\begin{array}{c}19 \\
(63.33 \%)\end{array}$ & $\begin{array}{c}11 \\
(36.67 \%)\end{array}$ & - & - & - & 4.63 & 0.49 & $\begin{array}{c}\text { Most } \\
\text { satisfied }\end{array}$ \\
\hline $\begin{array}{l}\text { 5. Suitability of course } \\
\text { contents }\end{array}$ & $\begin{array}{c}17 \\
(56.67 \%)\end{array}$ & $\begin{array}{c}13 \\
(43.33 \%)\end{array}$ & - & - & - & 4.57 & 0.50 & $\begin{array}{c}\text { Most } \\
\text { satisfied }\end{array}$ \\
\hline $\begin{array}{l}\text { 6. Suitability of } \\
\text { lecturers }\end{array}$ & $\begin{array}{c}21 \\
(70.00 \%)\end{array}$ & $\begin{array}{c}9 \\
(30.00 \%)\end{array}$ & - & - & - & 4.70 & 0.47 & $\begin{array}{c}\text { Most } \\
\text { satisfied }\end{array}$ \\
\hline 7. Training duration & $\begin{array}{c}18 \\
(60.00 \%)\end{array}$ & $\begin{array}{c}12 \\
(40.00 \%)\end{array}$ & - & - & - & 4.60 & 0.50 & $\begin{array}{c}\text { Most } \\
\text { satisfied }\end{array}$ \\
\hline 8. Training period & $\begin{array}{c}17 \\
(56.67 \%)\end{array}$ & $\begin{array}{c}13 \\
(43.33 \%)\end{array}$ & - & - & - & 4.57 & 0.50 & $\begin{array}{c}\text { Most } \\
\text { satisfied }\end{array}$ \\
\hline $\begin{array}{l}\text { 9. Worthiness } \\
\text { compared to wasted } \\
\text { time and cost }\end{array}$ & $\begin{array}{c}18 \\
(60.00 \%)\end{array}$ & $\begin{array}{c}12 \\
(40.00 \%)\end{array}$ & - & - & - & 4.60 & 0.50 & $\begin{array}{c}\text { Most } \\
\text { satisfied }\end{array}$ \\
\hline Summary & & & & & & 4.59 & 0.09 & $\begin{array}{c}\text { Most } \\
\text { satisfied }\end{array}$ \\
\hline
\end{tabular}

\section{Conclusions}

The cashew apple bagasse from cashew apple juice manufacturing was successfully developed as jam product. The jam production condition with the addition of $5 \%$ of cashew apple juice were the most favorable for sensory quality. The cashew apple bagasse jam was investigated the proximate composition, physical and chemical properties. The jam production technology was further transferred to local community via hands-on training processes obtaining the most satisfied level. This method has the potential to promote the cashew apple bagasse as a market product.

\section{Acknowledgements}

This work was supported by Walailak Culinary Training Center, Thailand. The cashew apple bagasse and cashew juice were obtained from Cashewy Phuket Cooperation Limited, Phuket, Thailand.

\section{References}

[1] EO Ogueji, SC Iheanacho, CE Mbah, AJ Yaji and U Ezemague. Effect of partial and complete replacement of soybean with discarded cashew nut (Anacardium occidentale L) on liver and stomach histology of Clarias gariepinus (Burchell, 1822). Aquacult. Fish. 2020; 5, 86-91.

[2] P Preethi, S Mangalassery, K Shradha, R Pandiselvam, MR Manikantan, SVR Reddy, SR Devi and MG Nayaka. Cashew apple pomace powder enriched the proximate, mineral, functional and structural properties of cereal based extrudates. LWT-Food Sci. Tech. 2021; 139, 110539.

[3] R Kaprasob, O Kerdchoechuen, N Laohakunjit, B Thumthanaruk and K Shetty. Changes in physicochemical, astringency, volatile compounds and antioxidant activity of fresh and concentrated cashew apple juice fermented with Lactobacillus plantarum. J. Food Sci. Tech. 2018; 55, 3979-90.

[4] S Junden. Development of dietary fiber supplemented sandwich bread from cashew pulp powder. In: Proceedings of the $4^{\text {th }}$ Suan Sunandha Academic National Conference on Research for Sustainable Development, Bangkok, Thailand. 2016, p. 161-72. 
[5] A Aleixandrea and M Miguel. Dietary fiber and blood pressure control. Food Funct. 2016; 7, 186471.

[6] C Chen, Y Zeng, J Xu, H Zheng, J Liu, R Fan, W Zhu, L Yuan, Y Qin, S Chen, Y Zhou, Y Wu, J Wan, M Mi and J Wang. Therapeutic effects of soluble dietary fiber consumption on type 2 diabetes mellitus. Exp. Ther. Med. 2016; 12, 1232-42.

[7] KPP Nair. The agronomy and economy of important tree crops of the developing world. Elsevier, Amsterdam, Netherlands, 2010.

[8] SS Singh, S. Abdullah, RC Pradhan and S Mishra. Physical, chemical, textural, and thermal properties of cashew apple fruit. J. Food Proc. Eng. 2019; 42, e13094.

[9] K Thangthong and K Huangrak. Factors affecting the qualities of Cashew fruit leather. King Mongkut's Agr. J. 2008; 26, 1-8.

[10] THS Rodrigues, GAS Pinto and LRB Gonçalves. Effects of inoculum concentration, temperature, and carbon sources on tannase production during solid state fermentation of cashew apple bagasse. Biotechnol. Bioproc. E. 2008; 13, 571-6.

[11] M Bekele, N Satheesh and JA Sadik. Screening of Ethiopian mango cultivars for suitability for preparing jam and determination of pectin, sugar, and acid effects on physico-chemical and sensory properties of mango jam. Sci. Afr. 2020; 7, e00277.

[12] A Nourmohammadi, E Ahmadi and A Heshmati. Optimization of physicochemical, textural, and rheological properties of sour cherry jam containing stevioside by using response surface methodology. Food Sci. Nutr. 2021; 9, 2483-96.

[13] Food Intelligence Center Thailand, Available at: http://fic.nfi.or.th/info_graphic_detail.php?id=22, accessed April 2021.

[14] AOAC. Official Methods of Analysis of AOAC International. $20^{\text {th }}$ eds. Gaithersburg, USA, 2016.

[15] H Stone and JL Sidel. Sensory evaluation practices: sensory evaluation. Academic Press, California, 2004.

[16] B Salehi, M Gültekin-Özgüven, C Kırkın, B Özçelik, MFB Morais-Braga, JNP Carneiro, CF Bezerra, TG Silva, HDM Coutinho, B Amina, L Armstrong, Z Selamoglu, M Sevindik, Z Yousaf, J Sharifi-Rad, AM Muddathir, HP Devkota, M Martorell, AK Jugran, N Martins and WC Cho. Anacardium plants: Chemical, Nutritional Composition and Biotechnological Applications. Biomolecules. 2019; 9, 465.

[17] HT Lawless and H Heymann. Sensory evaluation of food: Principles and practices. SpringerVerlag, New York, 2010.

[18] O Gouseti, A Lovegrove, O Kosik, PJ Fryer, C Mills, F Gates, G Tucker, C Latty, P Shewry and S Bakalis. Exploring the role of cereal dietary fiber in digestion. J. Agr. Food Chem. 2019; 67, 841924.

[19] YM Cassidy, EM McSorley and PJ Allsopp. Effect of soluble dietary fibre on postprandial blood glucose response and its potential as a functional food ingredient. J. Funct. Foods 2018; 46, 423-39.

[20] HE Khoo, A Azlan, ST Tang and SM Lim. Anthocyanidins and anthocyanins: Colored pigments as food, pharmaceutical ingredients, and the potential health benefits. Food Nutr. Res. 2017; 61, 1361779.

[21] JY Huang, JS Liao, JR Qi, WX Jiang and XQ Yang. Structural and physicochemical properties of pectin-rich dietary fiber prepared from citrus peel. Food Hydrocoll. 2021; 110, 106140.

[22] J Yan, J Hu, R Yang, Z Zhang and W Zhao. Innovative Nanofibrillated cellulose from rice straw as dietary fiber for enhanced health benefits prepared by a green and scale production method. ACS Sustain. Chem. Eng. 2018; 6, 3481-92.

[23] JC Encarnaçãoa, AS Pires, RA Amarala, TJ Gonçalvesa, M Laranjo, JE Casalta-Lopesa, AC Gonçalves, AB Sarmento-Ribeiro, AM Abrantes and MF Botelhoa. Butyrate, a dietary fiber derivative that improves irinotecan effect in colon cancer cells. J. Nutr. Biochem. 2018; 56, 183-92.

[24] MP McRae. The benefits of dietary fiber intake on reducing the risk of cancer: An umbrella review of meta-analyses. J. Chiropr. Med. 2018; 17, 90-6.

[25] Food and Drug Administration. Jam, jelly, and marmalade in sealed containers. Ministry of Public Health, Thailand, 2003.

[26] C Peerapatchara. The development of the packages for banana flour bakery. RMUTP Res. J. 2007; 1, 67-78. 